\title{
Molecular basis of a novel adaptation to hypoxic-hypercapnia in a strictly fossorial mole
}

\author{
Kevin L Campbell*1, Jay F Storz², Anthony V Signore1, Hideaki Moriyama², Kenneth C Catania³, Alexander P Payson4, \\ Joseph Bonaventura ${ }^{4}$, Jörg Stetefeld 5 and Roy E Weber 6
}

\begin{abstract}
Background: Elevated blood $\mathrm{O}_{2}$ affinity enhances survival at low $\mathrm{O}_{2}$ pressures, and is perhaps the best known and most broadly accepted evolutionary adjustment of terrestrial vertebrates to environmental hypoxia. This phenotype arises by increasing the intrinsic $\mathrm{O}_{2}$ affinity of the hemoglobin $(\mathrm{Hb})$ molecule, by decreasing the intracellular concentration of allosteric effectors (e.g., 2,3-diphosphoglycerate; DPG), or by suppressing the sensitivity of Hb to these physiological cofactors.

Results: Here we report that strictly fossorial eastern moles (Scalopus aquaticus) have evolved a low $\mathrm{O}_{2}$ affinity, DPGinsensitive $\mathrm{Hb}$ - contrary to expectations for a mammalian species that is adapted to the chronic hypoxia and hypercapnia of subterranean burrow systems. Molecular modelling indicates that this functional shift is principally attributable to a single charge altering amino acid substitution in the $\beta$-type $\delta$-globin chain ( $\delta 136 \mathrm{Gly} \rightarrow \mathrm{Glu}$ ) of this species that perturbs electrostatic interactions between the dimer subunits via formation of an intra-chain salt-bridge with $\delta 82 \mathrm{Lys}$. However, this replacement also abolishes key binding sites for the red blood cell effectors $\mathrm{Cl}$, lactate and DPG (the latter of which is virtually absent from the red cells of this species) at $\delta 82 \mathrm{Lys}$, thereby markedly reducing competition for carbamate formation ( $\mathrm{CO}_{2}$ binding) at the $\delta$-chain $\mathrm{N}$-termini.
\end{abstract}

Conclusions: We propose this $\mathrm{Hb}$ phenotype illustrates a novel mechanism for adaptively elevating the $\mathrm{CO}_{2}$ carrying capacity of eastern mole blood during burst tunnelling activities associated with subterranean habitation.

\section{Background}

Among mammals that are adapted to hypoxic environments, only subterranean species are also obliged to breathe air with elevated concentrations of carbon dioxide [1]. Within this select group, the 25 or so species of fossorial moles (Family Talpidae) are among the few that live exclusively underground. These small (70-130 g) insectivores favour moist, invertebrate-rich substrates to excavate extensive closed-burrow systems. Due to the impeded gas exchange of damp soils with surface air, these animals are chronically exposed to hypoxic and hypercapnic environments $\left(14.3 \% \mathrm{O}_{2}\right.$ and $5.5 \% \mathrm{CO}_{2}$ have been recorded within mole tunnels; [2]). The high metabolic costs of burrowing, in terms of $\mathrm{O}_{2}$ consumption and $\mathrm{CO}_{2}$ production, are exacerbated by the obligate re-

* Correspondence: campbelk@cc.umanitoba.ca

${ }^{1}$ Department of Biological Sciences, University of Manitoba, Winnipeg, MB R3T 2N2 Canada

Full list of author information is available at the end of the article breathing of expired air while tunnelling, and may therefore require adaptive modifications in hemoglobin $(\mathrm{Hb})$ function. Not surprisingly, whole blood $\mathrm{O}_{2}$ affinity of the European mole, Talpa europaea, is much higher (its half saturation $\mathrm{O}_{2}$ pressure or $\mathrm{P}_{50}$ is $10-15 \mathrm{~mm} \mathrm{Hg}$ lower) than those of terrestrial mammals of similar size $[1,3,4]$. This feature has been attributed to a reduced affinity of European mole $\mathrm{Hb}$ for 2,3-diphosphoglycerate (DPG) [4,5], which binds to a cluster of positively charged residues between the $\beta$-type chains and stabilizes the low affinity (deoxy) conformation of the molecule. However, it is not known whether other fossorial members of the family Talpidae possess similar specializations to the subterranean environment. This question is of interest in light of recent evidence which suggests that New World (Scalopini) and Old World (Talpini) moles have convergently invaded the subterranean habitat [[6,7], but see [8]; Figure 1]. 


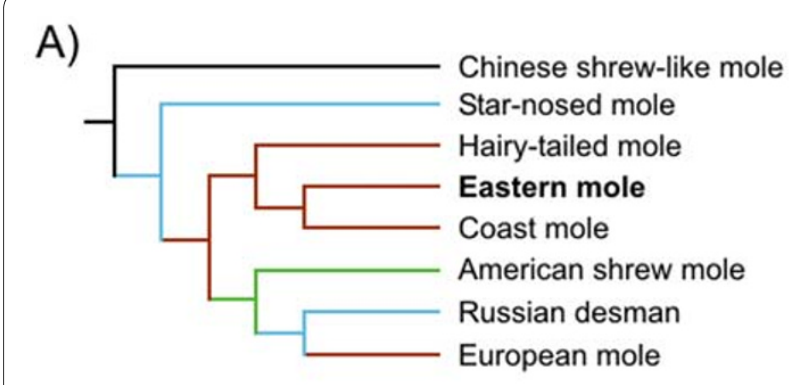

B)

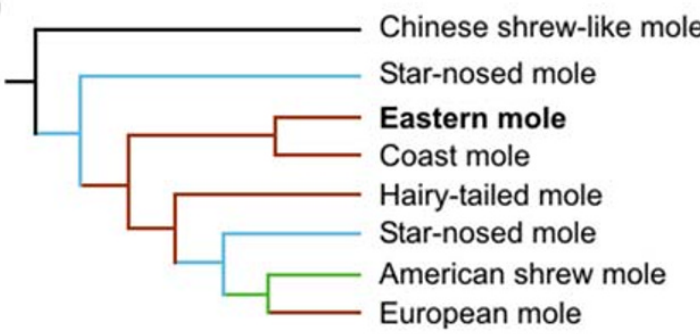

C)

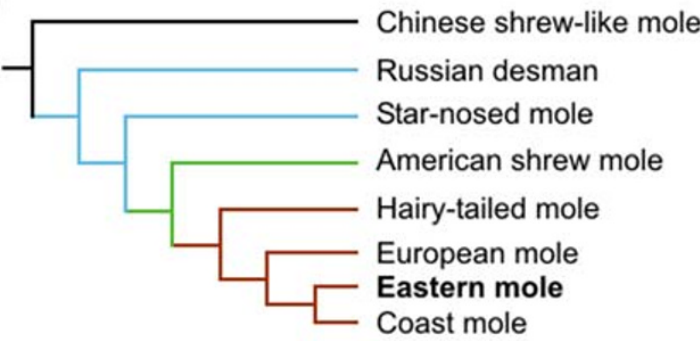

Figure 1 Phylogenetic hypothesis of the Family Talpidae. (A) Shinohara et al. 2003 [6], (B) Motokawa 2004 [7], and (C) Whidden 2000 [8]. Line colours refer to the habitats exploited by each: high-alpine terrestrial (black), semi-aquatic (blue), fossorial (brown) and semi-fossorial (green). Note that all topologies suggest that the lineage leading towards present-day eastern moles arose following an extensive period of fossorial evolution.

In order to assess the functional and evolutionary adaptations of mole Hbs, and their mechanistic basis, we determined the coding sequences of the adult-expressed $\alpha$-and $\beta$-type globin chains of coast mole (Scapanus orarius) and eastern mole (Scalopus aquaticus), two closely related, strictly fossorial species that are endemic to Western and Eastern North America, respectively, and we investigated the ligand-binding properties of their $\mathrm{Hb}$ components. Based on unexpected findings for S. aquaticus $\mathrm{Hb}$, we also measured oxygen-binding properties of whole blood for both species and the semi-aquatic starnosed mole (Condylura cristata). To gauge whether the distinctive oxygenation properties of eastern mole $\mathrm{Hb}$ are accompanied by complementary or compensatory physiological adjustments, we also measured hematological and muscle biochemical properties of the two fossorial species.

\section{Results}

\section{$\mathrm{Hb}-\mathrm{O}_{2}$ binding properties}

Both gel electrophoresis and isoelectric focusing (IEF; inset of Figure 2) revealed the presence of two major isoHb components (the tetrameric Hbs of each component possess distinct $\alpha$-type globin chains; see below) in all individuals examined ( $n=3$ coast moles; $n=4$ eastern moles), where the $\mathrm{Hb}$ I:Hb II ratio approximated 60:40 and 35:65, respectively. In addition to these major components, one of the eastern mole specimens possessed a minor cathodic $\mathrm{Hb}$ component that represented $\sim 5 \%$ of the hemolysate and exhibited oxygen-binding properties similar to those of the major components (data not shown). Preparative IEF revealed relatively high isoelectric points (the $\mathrm{pH}$ at which the protein carries a net neutral charge) for the CO-bound $\mathrm{Hb}$ components of both species at $5^{\circ} \mathrm{C}$ (inset of Figure 2).

Oxygen equilibration curves revealed striking functional differences between the Hbs of the two species (Figure 2), with 'stripped' (cofactor-free) Hbs of the eastern mole exhibiting $\mathrm{P}_{50}$ 's $(13.8$ and $14.8 \mathrm{~mm} \mathrm{Hg}$ for Hbs I and $\mathrm{Hb} \mathrm{II}$, respectively, at $37^{\circ} \mathrm{C}, \mathrm{pH} 7.2$ ) that are nearly three-fold higher than those of the coast mole $\left(\mathrm{P}_{50}=5.3\right.$ and $5.1 \mathrm{~mm} \mathrm{Hg}$, respectively). Eastern mole $\mathrm{Hbs}$ also exhibited slightly lower chloride sensitivities $\left(\Delta \log \mathrm{P}_{50} /\right.$ $\Delta \log \left[\mathrm{Cl}^{-}\right]$; Table 1$)$, though the $\mathrm{Hbs}$ of both species showed similar cooperativity coefficients (Figure 2). Significantly, the $\mathrm{O}_{2}$-affinity of coast mole Hbs was sharply reduced in the presence of saturating concentrations of DPG, a trait not observed in eastern mole Hbs (Table 1, Figure 2). Even under saturating DPG concentrations the $\mathrm{P}_{50}$ of coast mole $\mathrm{Hbs}(18.3-19.7 \mathrm{~mm} \mathrm{Hg}$ at $\mathrm{pH} 7.2)$ remained lower than those of eastern mole $\mathrm{Hbs}$ in the absence of this organophosphate $(22.2-26.0 \mathrm{~mm} \mathrm{Hg}$; Figure 2). Similarly, oxygenation enthalpies $(\Delta H)$ of coast mole $\mathrm{Hbs}$ at $\mathrm{pH} 7.2$ and in $0.1 \mathrm{M} \mathrm{Cl}^{-}$media $(-7.6$ to $-9.7 \mathrm{~kJ}$ $\mathrm{mol}^{-1} \mathrm{O}_{2}$; Table 1) were lower than those of eastern moles $\left(-10.3\right.$ to $\left.-13.7 \mathrm{~kJ} \mathrm{~mol}^{-1}\right)$, though both were low compared to human $\mathrm{Hb}$ A at pH $7.4\left(-41.0 \mathrm{~kJ} \mathrm{~mol}^{-1}\right.$; [9]).

\section{$\mathrm{O}_{2}$-binding properties of whole blood}

In accordance with the observed differences in the oxygen affinity of coast vs. eastern mole $\mathrm{Hb}$ components in the presence of allosteric effectors (Figure 2), the $\mathrm{P}_{50}$ of freshly drawn coast mole blood $\left(17.7 \mathrm{~mm} \mathrm{Hg}\right.$ at $\left.36^{\circ} \mathrm{C}\right)$ was substantially lower than that from the eastern mole $(28.8$ $\mathrm{mm} \mathrm{Hg}$ ), while that of the amphibious star-nosed mole was intermediate (22.5 mm Hg; Figure 3, Table 2). However, whole blood $\mathrm{pH}$ was notably lower in eastern mole $(\mathrm{pH}=7.38)$ than in the coast and star-nosed moles $(7.60$ and 7.55, respectively). Even when corrected to $\mathrm{pH} 7.4$, a clear difference in whole-blood $\mathrm{O}_{2}$-affinity of these two 


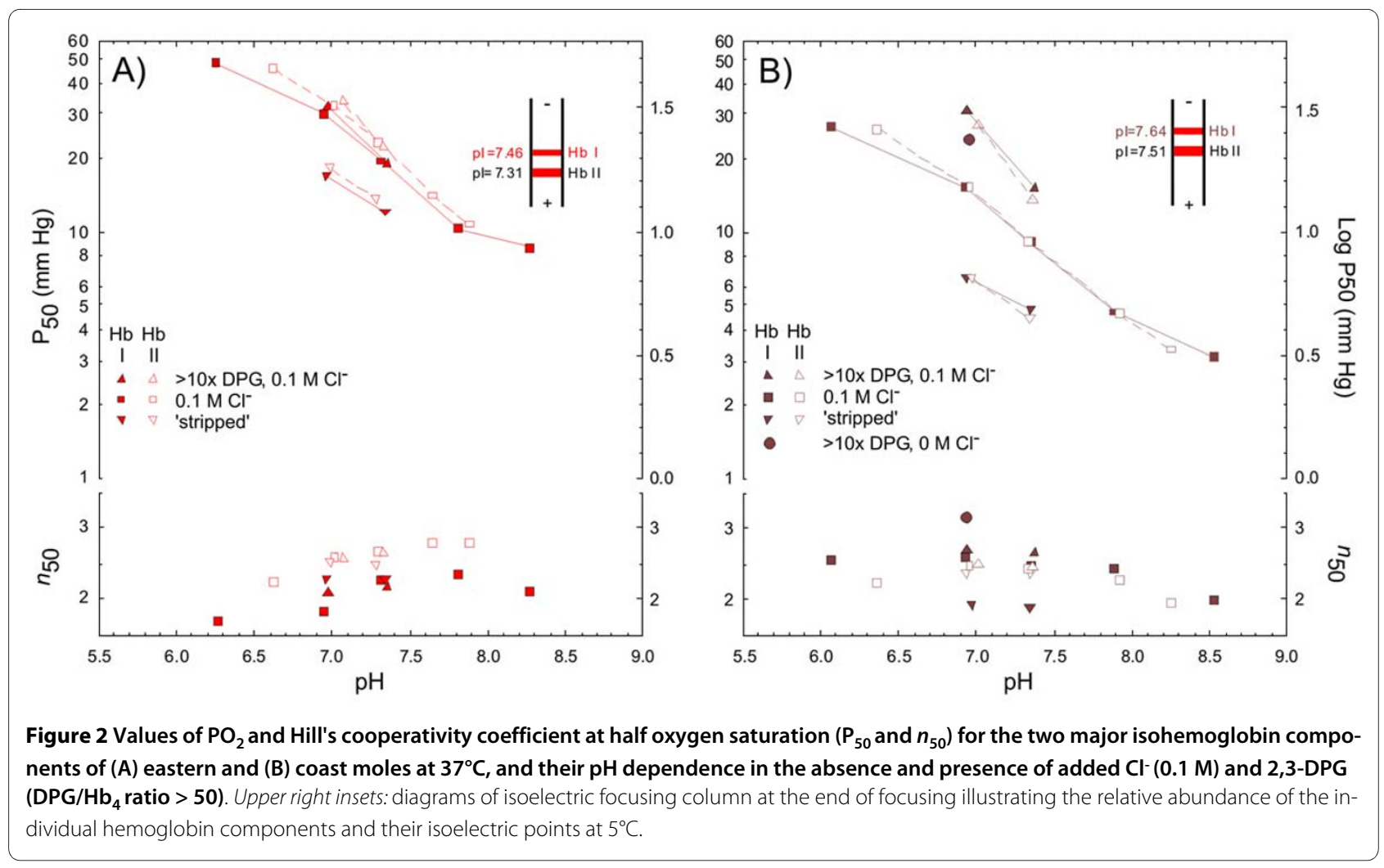

Table 1: Heterotropic effects at half-saturation $\left(P_{50}\right)$ for coast and eastern mole hemoglobin

\begin{tabular}{|c|c|c|c|c|}
\hline & \multicolumn{2}{|c|}{ Eastern mole } & \multicolumn{2}{|c|}{ Coast mole } \\
\hline & $\mathbf{H b} \mathbf{I}$ & $\mathbf{H b} \|$ & $\mathbf{H b ~ I}$ & Hb II \\
\hline$\Delta \log \mathrm{P}_{50} / \Delta \log \left[\mathrm{Cl}^{-}\right]^{1,2}$ & 0.21 & 0.25 & 0.31 & 0.33 \\
\hline$\Delta \log P_{50} \pm 2.5 m M ~ D P G 1,3$ & 0.02 & 0.02 & 0.26 & 0.23 \\
\hline \multicolumn{5}{|l|}{$\Delta \log \mathrm{P}_{50} / \Delta \mathrm{pH}^{4}$} \\
\hline $25^{\circ} \mathrm{C}, 0.1 \mathrm{M} \mathrm{Cl}^{-}$ & -0.57 & -0.61 & -0.55 & -0.62 \\
\hline $37^{\circ} \mathrm{C}$, 'stripped' & -0.40 & -0.41 & -0.32 & -0.44 \\
\hline $37^{\circ} \mathrm{C}, 0.1 \mathrm{M} \mathrm{Cl}^{-}$ & -0.51 & -0.52 & -0.54 & -0.59 \\
\hline $37^{\circ} \mathrm{C}, 0.1 \mathrm{M} \mathrm{Cl}^{-}+2.5 \mathrm{mM} \mathrm{DPG}$ & -0.63 & -0.73 & -0.86 & -0.78 \\
\hline Oxygenation enthalpy; $\Delta H\left(\mathrm{~kJ} \mathrm{~mol}^{-1} \mathrm{O}_{2}\right)^{5}$ & -13.7 & -10.3 & -9.7 & -7.6 \\
\hline
\end{tabular}

${ }^{1} \mathrm{pH}=7.2$

${ }^{2}[\mathrm{DPG}]=0 \mathrm{mM}$

$3[\mathrm{Cl}]=0.1 \mathrm{M}$

${ }^{4}$ Over $\mathrm{pH}$ range 6.9-7.4; $\mathrm{PCO}_{2}=0 \mathrm{~mm} \mathrm{Hg}$

${ }^{5}[\mathrm{Cl}]=0.1 \mathrm{M} ;[\mathrm{DPG}]=0 \mathrm{mM} ; \mathrm{pH}=7.2$ 


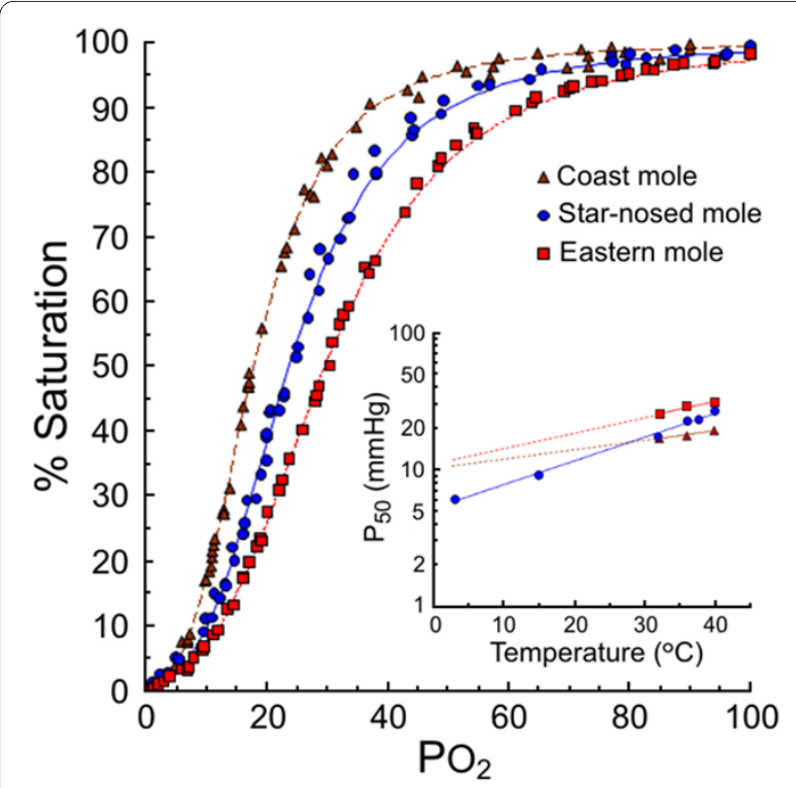

Figure 3 Oxygen equilibration curves of freshly drawn coast ( $\square$ ) eastern $(\Delta)$ and star-nosed mole $(\Theta)$ blood at $36^{\circ} \mathrm{C}$ and a $\mathrm{PCO}_{2}$ of $\mathbf{3 8} \mathbf{~ m m ~ H g}$. Inset: The effect of temperature on the half-saturation pressure $\left(P_{50}\right)$ of whole blood of these three species.

fossorial species was evident $\left(\mathrm{P}_{50}=21.9\right.$ vs. $26.9 \mathrm{~mm} \mathrm{Hg}$, respectively). The $\mathrm{CO}_{2}$ Bohr coefficients (determined by measurements whereby the $\mathrm{pH}$ is changed by varying $\left.\mathrm{PCO}_{2}\right)$ of blood from coast mole $(-0.52)$ and star-nosed mole $(-0.40)$ were within the typical mammalian range (0.39 to -0.62 ; [10]), while that of the eastern mole was unusually high (-0.78; Table 2). Consistent with our $\mathrm{Hb}$ data, the blood $\mathrm{P}_{50}$ values of both fossorial species showed low temperature sensitivities, with the Hb-oxygenation reaction being less exothermic in coast mole $\left(\Delta H=-1.0 \mathrm{~kJ} \mathrm{~mol}^{-1} \mathrm{O}_{2}\right.$; Table 2) than in the eastern mole ($\left.8.3 \mathrm{~kJ} \mathrm{~mol}^{-1}\right)$. Surprisingly, blood- $\mathrm{O}_{2}$ affinity of the semiaquatic star-nosed mole was more strongly governed by temperature (inset of Figure 3), as reflected by its high oxygenation enthalpy $\left(-29.9 \mathrm{~kJ} \mathrm{~mol}^{-1} \mathrm{O}_{2}\right.$; Table 2) relative to the fossorial mole species.

Prominent differences were also detected in specific hematological parameters of the two fossorial species, with the most significant being the $>15$ fold lower DPG levels in the erythrocytes of eastern mole relative to coast mole (Table 3). Tissue myoglobin concentration was also consistently lower in eastern moles (by 10-20\%), although this difference was only significant for hindlimb muscles. Conversely, hematocrit and $\mathrm{Hb}$ concentrations were $20.5 \%$ and $10.3 \%$ higher, respectively, in eastern mole blood than in coast mole blood (Table 3).

\section{Identification of $\mathrm{Hb}$ isoforms}

One $\beta$-like and two $\alpha$-like globin cDNAs were obtained from three separate eastern moles, while single $\alpha$ - and $\beta$ - like globin cDNAs were obtained from three coast moles examined (Figure 4). A mass spectrometic analysis of eastern mole $\mathrm{Hb}$ components revealed the presence of two distinct $\alpha$-globin sequences that match the two known $H B A$ cDNA sequences (' $\alpha 1$ ' and ' $\alpha 2$ '; Figure 4). The analysis revealed the presence of a single $\beta$-like globin sequence that matched the eastern mole $H B D(\delta)$ cDNA sequence (see below). These results confirm that the two $\mathrm{Hb}$ isoforms of eastern mole have different $\alpha$ chain subunits that are distinguished by three amino acid substitutions: $\quad$ 48Leu $\rightarrow$ Met, $\quad$ 49Lys $\rightarrow$ Ser, and $121 \mathrm{Met} \rightarrow \operatorname{Val}(\alpha 1 \rightarrow \alpha 2$ in each case). The mass spectrometry analysis of coast mole $\mathrm{Hb}$ also revealed highly significant matches to coast mole cDNA sequences. However, since the analysis revealed no evidence for structurally distinct $\mathrm{Hb}$ isoforms, the distinct bands in the isoelectric focusing gels likely reflect some form of in vivo posttranslational modification. The electrophoretic mobility patterns of the two fractions (inset of Figure 2B) are consistent with a deamidation reaction, whereby a portion of the amide side-chain moieties of specific Asn or Gln residues of $\mathrm{Hb}$ are converted to carboxyl groups $[11,12]$. Based on the primary sequences of the coast mole globin chains (Figure 4), the most probable scenario is deamidation of $\alpha 60$ Asn $\rightarrow$ Asp, which is adjacent to two residues ( $\alpha 58$ His and $\alpha 59$ Gly) that are often associated with this non-enzymatic reaction $[11,12]$.

\section{Phylogenetic analyses of mole $\beta$-like genes}

Phylogenetic surveys of the $\beta$-globin gene family have revealed that, in most mammalian species, the $\beta$-type globin chains of adult $\mathrm{Hb}$ are encoded by one or more copies of the $H B B(\beta)$ gene $[13,14]$. However, in the eulipotyphlan (moles, shrews, hedgehogs and solenodons) species that have been examined to date (Eurasian shrew, Sorex araneus, and African pygmy hedgehog, Atelerix albiventris) the $\beta$-type globin chains of adult $\mathrm{Hb}$ are encoded by multiple copies of the paralogous $H B D(\delta)$ gene [13]. Because recent molecular phylogenies now suggest that Sorex and Atelerix are sister taxa and are closely related to moles [15], it is still unknown whether $H B D$ supplanted the $H B B$ gene before or after the shrew/ hedgehog common ancestor diverged from the stem lineage of talpid moles.

We used phylogenetic reconstructions of coding sequences and intron 2 sequences to determine whether the $\beta$-like globin genes of eastern mole and coast mole are orthologous to the $H B B$ or $H B D$ genes of other eutherian mammals. Phylogenetic reconstructions based on coding sequence indicated that orthologous relationships may be partly obscured by a history of concerted evolution, mediated by unequal crossing-over or interparalog gene conversion (a form of nonreciprocal recombination between duplicated genes) [13]. For example, a history of gene conversion is indicated by the fact that the human 
Table 2: Respiratory characteristics of eastern, coast and star-nosed mole whole blood

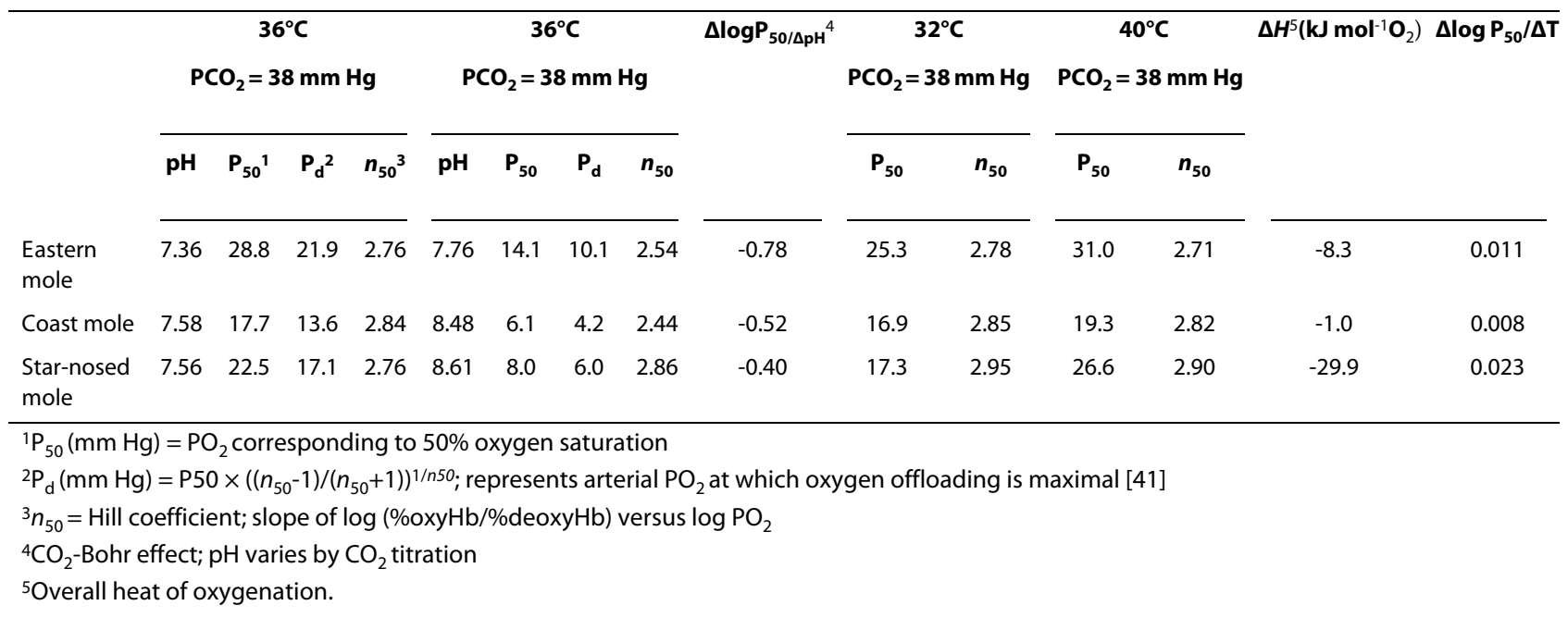

$H B B$ gene is more similar to the human $H B D$ gene than it is to the orthologous $H B B$ gene in rabbit or armadillo (Figure 5A). By contrast, the phylogeny based on intron 2 sequence shows that the $\beta$-like globin genes of all eulipotyphlan species examined - together with the $H B D$ genes of human, rabbit, and armadillo - form a well-supported monophyletic group with high bootstrap support (Figure $5 \mathrm{~B})$. This set of relationships indicates that the adultexpressed $\beta$-like globin genes of moles are orthologous to the $H B D$ genes of other eutherian mammals. Thus, the $H B D$ gene appears to have supplanted the $H B B$ gene in the common ancestor of shrews, hedgehogs and moles.

\section{Discussion}

The pioneering work of Bunn [16] demonstrated that mammalian Hbs fall into two discrete categories based on their ligand-binding properties. Most species have Hbs with intrinsically high $\mathrm{O}_{2}$ affinity that is markedly reduced in the red cell by physiological concentrations of DPG (4-10 $\mathrm{mM} \mathrm{l}^{-1} \mathrm{RBC}$ ), which stabilizes the tense (deoxy) state of $\mathrm{Hb}$ by electrostatic binding within a cationic pocket (formed by $\beta 1 \mathrm{Val}, \beta 2 \mathrm{His}, \beta 82 \mathrm{Lys}$ and $\beta 143 \mathrm{His})$ between the $\beta$-chains [17]. Conversely, the Hbs of feloids, ruminants and two species of lemur exhibit low $\mathrm{O}_{2}$ affinities and respond only weakly to organophosphates [17], which moreover occur in low concentrations in the red cells [16]. The $\beta$-type chains of these animals share two features without exception: the substitution of a hydrophilic residue with a hydrophobic residue at $\beta 2$ [18], and the presence of $\beta 5 A$ Ala. The latter residue is thought to give the first turn of helix A more flexibility [19], allowing the modified N-termini to be drawn closer to the hydrophobic cavity between the $\beta$ chains and thus mimicking DPG binding [18].
Though $85 \mathrm{Ala}$ is present in eastern (and coast) moles, contrary to our expectations, all known phosphate-binding sites are conserved in the $\beta$-type $\delta$-chains of moles (Figure 4). Significantly, however, eastern moles possess a novel $\delta 136 \mathrm{Gly} \rightarrow$ Glu replacement that introduces two anionic residues into the positively charged central cavity of the $\mathrm{Hb}$ tetramer. This position is essentially invariant among mammals. However, a rare $\mathrm{Hb}$ mutant in humans, $\mathrm{Hb}$ Hope, is characterized by a comparable charge altering replacement ( $\beta 136$ Gly $\rightarrow$ Asp) and, interestingly, exhibits functional properties similar to that of eastern mole $\mathrm{Hb}[20,21]$. It has been proposed that the altered behaviour of $\mathrm{Hb}$ Hope arises from the formation of an intra-chain salt bridge between the carboxyl ( $\left.\mathrm{COO}^{-}\right)$ group of $\beta 136 \mathrm{Asp}$ and the charged $\alpha$-amino group $\left(\mathrm{NH}_{2}{ }^{+}\right)$ of $\beta 1 \mathrm{Val}$ [22], thus deleting a pair of DPG binding sites and stabilizing the T-state molecule via the newly established ionic linkage $[21,23,24]$. However, the electrophoretic properties of $\mathrm{Hb}$ Hope remain unchanged at $\mathrm{pH} 8.6$ [25], where the $\mathrm{N}$-terminius is expected to be deprotonated (its $\mathrm{pKa}$ is $\sim 6.4-6.8$; $[26,27]$ ) and the $\beta 1$ Val$\beta 136$ Asp salt-bridge thus destabilized. Additionally, given that this proposed interaction deletes a maximum of two (of seven) docking sites for DPG, the near complete abolishment of organophosphate binding to $\mathrm{Hb}$ Hope is difficult to explain. Indeed, $\mathrm{Hb}$ variants that lack DPG binding sites at the $\mathrm{N}$-terminus (e.g., $\mathrm{Hb}$ Raleigh $\beta 1 \mathrm{Val} \rightarrow$ Ac-Ala; $[28]$ ), at $\beta 2$ (e.g., $\mathrm{Hb}$ Fukuoka $\beta 2 \mathrm{His} \rightarrow$ Tyr, Hb Okayama His $\rightarrow$ Gln; [29]) and at $\beta 143$ (e.g., Hb Little Rock, $\beta 143$ His $\rightarrow$ Gln; [30]) only exhibit modest reductions in DPG sensitivity. These inconsistencies suggest another molecular mechanism may underlie the drastic functional changes found in Hb Hope and the eastern mole protein. 
Table 3: Hematological parameters, skeletal muscle myoglobin concentrations and buffering capacities ( \pm 1 SE) of coast and eastern moles (samples sizes are indicated in brackets)

\begin{tabular}{lcc}
\hline Variable & Eastern mole & Coast mole \\
\hline Hematocrit (\%) & $56.4 \pm 1.3(7)^{\dagger}$ & $46.8 \pm 2.0(11)^{1}$ \\
Hemoglobin $\left(\mathrm{g} \mathrm{dL}^{-1}\right)$ & $19.2 \pm 0.7(7)$ & $17.4 \pm 0.8(11)^{1}$ \\
$\mathrm{RBC}\left(10^{6} / \mathrm{mm}^{3}\right)$ & $12.58 \pm 0.32(3)$ & $10.48(1)$ \\
MCV $\left(\mu^{3}\right)$ & $46.0 \pm 1.3(3)$ & $42.6(1)$ \\
MCH $(\mathrm{pg})$ & $15.3 \pm 0.6(3)$ & $13.5(1)$ \\
MCHC (g L-1) & $333 \pm 7(3)$ & $318(1)$ \\
2,3-DPG (mM L-1 RBC) & $0.45 \pm 0.06(4)^{\dagger}$ & $7.09 \pm 0.20(3)$ \\
Myoglobin content (mg g-1 wet tissue) & & $9.24 \pm 0.28(7)^{1}$ \\
$\quad$ Heart & $8.34 \pm 0.38(6)$ & $12.10 \pm 0.25(10)^{1}$ \\
Forelimb & $10.98 \pm 0.64(6)$ & $10.61 \pm 0.56(10)^{1}$ \\
$\quad$ Hindlimb & $8.56 \pm 0.21(6)^{\dagger}$ & $37.33 \pm 2.10(10)^{1}$ \\
Buffering capacity, $\beta($ Slykes) & & $38.94 \pm 1.77(10)^{1}$ \\
$\quad$ Forelimb & & --
\end{tabular}

†Interspecific differences are significant $(P<0.05)$

${ }^{*} 1$ Slyke $=\mu$ moles of base required to titrate the $\mathrm{pH}$ of $1 \mathrm{~g}$ of wet muscle by $1 \mathrm{pH}$ unit

1 data from [45]

In accord with this suggestion, our structural model illustrates that the carboxyl side chain of $8136 \mathrm{Glu}$ forms a stable salt bridge with the nearby $\varepsilon$-amino group of 882Lys (Figure 6). This association is consistent with the observed low electrophoretic mobility of $\mathrm{Hb}$ Hope at $\mathrm{pH}$ 8.6 [25], as the high pKa of the lysine side chain $(\sim 10.5)$ would stabilize the strong $\beta 136$ Asp- $\beta 82$ Lys bond over a wide $\mathrm{pH}$ range. Importantly, the $\delta 136 \mathrm{Gly} \rightarrow$ Glu replacement in eastern mole $\mathrm{Hb}$ (and the $\beta 136 \mathrm{Gly} \rightarrow$ Asp change in $\mathrm{Hb}$ Hope) is also expected to neutralize the strong cationic charge of the $\delta 82$ lysyl side chain (which normally projects directly into the central cavity). This substitution should reduce electrostatic repulsion between the dimer subunits [19,31], thereby reducing the intrinsic $\mathrm{O}_{2}$ affinity of the R-state protein. Consistent with this expectation, the intrinsic $\mathrm{O}_{2}$ affinity of eastern mole $\mathrm{Hb}$ is $\sim 2.8$-fold lower than that of coast mole $\mathrm{Hb}$ in the physiological $\mathrm{pH}$ range (Figure 2). Finally, the strongly suppressed DPG sensitivities of human $\mathrm{Hbs}$ with residue replacements at $\beta 82$ (e.g., Hb Rahere $\beta 82 \mathrm{Lys} \rightarrow \mathrm{Thr}$ and Hb Providence $\beta 82$ Lys $\rightarrow$ Asn/Asp; $[32,33]$ ) are qualitatively similar in magnitude to that of eastern mole $\mathrm{Hb}$ (Figure 2, Table 1). In this regard, it is notable that eastern moles also possess an unusual $\delta 3$ Leu $\rightarrow$ Met substitution in the $\mathrm{N}$-terminal region of the $\delta$-chains (Figure 4). Aided by the increased flexibility provided by residues $\delta 5 \mathrm{Ala}$ and $\delta 130 \mathrm{Phe}[19]$, the longer side-chain of this residue (which points internally towards $\delta 133 \mathrm{Met}$ ) may promote an increased interaction of the $\beta$-type subunit A-helix with its hydrophobic core, and further inhibit DPG binding (an analogous residue change found in human fetal $\mathrm{Hb}, \gamma 3 \mathrm{Leu} \rightarrow \mathrm{Phe}$, is implicated in reducing the affinity of this respiratory protein for $\mathrm{O}_{2}$ and DPG [34]). Finally, the eastern mole $\delta$ globin chains possess an additional, potentially significant replacement that introduces a polar hydroxyl group $(\delta 128 \mathrm{Ala} \rightarrow \mathrm{Thr})$ into the $\alpha_{1} \delta_{1}$ interface. This site is typically invariant in mammalian $\mathrm{Hbs}[22,35]$ and may be responsible for the larger $\mathrm{P}_{50}$ difference between cofactorfree $\mathrm{Hbs}$ of eastern mole and coast mole (2.6-2.9 fold at $37^{\circ} \mathrm{C}$; Figure 2) than the 1.8 -fold change caused by the $\beta 136 \mathrm{Gly} \rightarrow$ Asp substitution of $\mathrm{Hb}$ Hope at this same temperature [20].

The chloride sensitivities of both major Hb components of the eastern mole (0.21-0.25) are about $30 \%$ less than those of coast mole Hbs (Table 1). Hb Hope also exhibits a markedly lowered $\mathrm{Cl}^{-}$effect relative to $\mathrm{Hb} \mathrm{A}$ [21], providing additional support for the view that this characteristic arises from the loss of two anion binding sites in the eastern mole protein (i.e., between $\delta 1 \mathrm{Val}$ and 


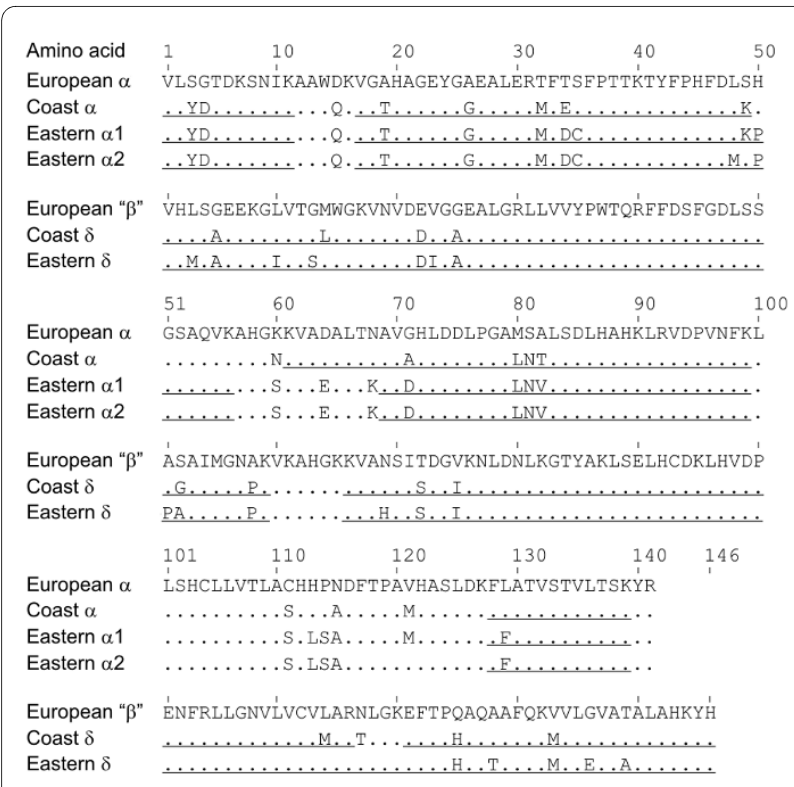

Figure 4 Alignment of mole $\boldsymbol{\alpha}$ - and $\boldsymbol{\delta}$-globin chains. Amino acid residues of coast and eastern moles were deduced from cDNA nucleotide sequences and are shown only at positions where they differ from those of European moles [5]. The underlined portions of each amino acid sequence denote the coverage of matched peptides in the mass spectrometry analysis (see text for details).

882Lys of each dimer; see Figure 6A). However, it is of note that the $\mathrm{P}_{50}$ of coast mole $\mathrm{Hb}$ I exposed to saturating DPG in $0.1 \mathrm{M} \mathrm{Cl}^{-}$media was higher than values obtained when either of these anions were present alone (Figure 3). This observation suggests that mole Hbs possess an extra chloride-binding site (with respect to human $\mathrm{Hb} \mathrm{A}$ ) that does not overlap with the DPG binding site. This inference is moreover consistent with the numerically low oxygenation enthalpies (see below) of both mole $\mathrm{Hbs}$ in $0.1 \mathrm{M} \mathrm{Cl}^{-}$media (Table 1 ).

The $7.3 \mathrm{~kJ} \mathrm{~mol}^{-1} \mathrm{O}_{2}$ difference in overall oxygenation enthalpy of eastern mole whole blood relative to coast mole blood (Table 2) aligns well with the reduced exothermic contributions conferred by both the loss of $\mathrm{Cl}^{-}$ binding sites between $\delta 1 \mathrm{Val}$ and $\delta 82 \mathrm{Lys}\left(-3.4 \mathrm{~kJ} \mathrm{~mol}^{-1} \mathrm{O}_{2}\right.$; Table 1$)$, and by a lack of DPG binding $\left(-3.1 \mathrm{~kJ} \mathrm{~mol}^{-1} \mathrm{O}_{2}\right.$; [36]) to eastern mole $\mathrm{Hb}$. Interestingly, the numerical $\Delta H$ values for whole blood (-1.0 to $-8.3 \mathrm{~kJ} \mathrm{~mol}^{-1} \mathrm{O}_{2}$; Table 2) and purified $\mathrm{Hbs}\left(-7.6\right.$ to $-13.7 \mathrm{~kJ} \mathrm{~mol}^{-1}$; Table 1$)$ of coast and eastern moles, respectively, are notably lower than those reported for both whole blood (-16.8 and $-14.4 \mathrm{~kJ}$ $\mathrm{mol}^{-1}$, respectively [37]) and the $\mathrm{Hb}$ fractions (-14.0 and $15.0 \mathrm{~kJ} \mathrm{~mol}^{-1}$, respectively [9]) of 'cold-adapted' musk-ox and reindeer. Given that possession of blood with numerically low oxygenation enthalpies helps to ensure adequate $\mathrm{O}_{2}$ delivery to cool peripheral tissues of these Arctic mammals [37], and that subterranean environ-

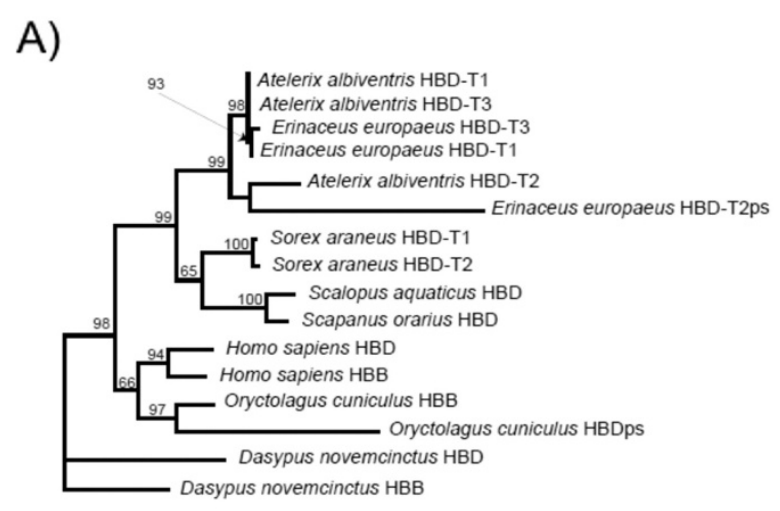

B)

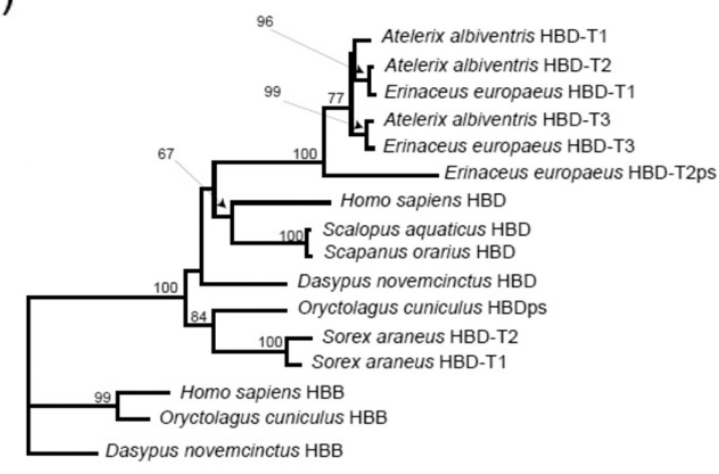

Figure 5 Phylogenetic analysis of mole $\boldsymbol{\beta}$-like globin genes. Maximum likelihood phylograms depicting relationships among mammalian $\beta$-like globin genes based on (A) 477 bp of coding sequence, and (B) $938 \mathrm{bp}$ of intron 2. With the exception of the sequences from eastern mole (Scalopus aquaticus) and coast mole (Scapanus orarius), all $\beta$ like globin sequences were retrieved from full genome assemblies (see text for details). Both trees demonstrate that the $\beta$-like globin genes of Scalopus and Scapanus are orthologous to the HBD genes of other mammals. Because mammals typically possess multiple tandemly duplicated copies of adult beta-like globin genes, we index each paralog with the symbol -T followed by a number that corresponds to the $5^{\prime}$ to ' 3 ' linkage order. Pseudogene sequences are indicated by the suffix 'ps'.

ments are generally moderate and thermally buffered from climatic extremes, what might account for the occurrence of this characteristic in the fossorial species (Figure 3, Table 2) but not in the (northerly distributed) semi-aquatic star-nosed mole? By mandating that blood$\mathrm{O}_{2}$ affinity decreases as temperature increases, the exothermic character of the $\mathrm{Hb}$ oxygenation reaction also dictates that $\mathrm{O}_{2}$ uptake is compromised at high temperature. Unlike most fossorial mammals, talpid moles are powerful forelimb diggers that possess a large muscle mass surrounding the thoracic cavity. Consequently, we propose that the negligible thermal sensitivity of mole blood may minimize impairment of $\mathrm{O}_{2}$ loading at the lungs during exercise-induced hyperthermia while bur- 

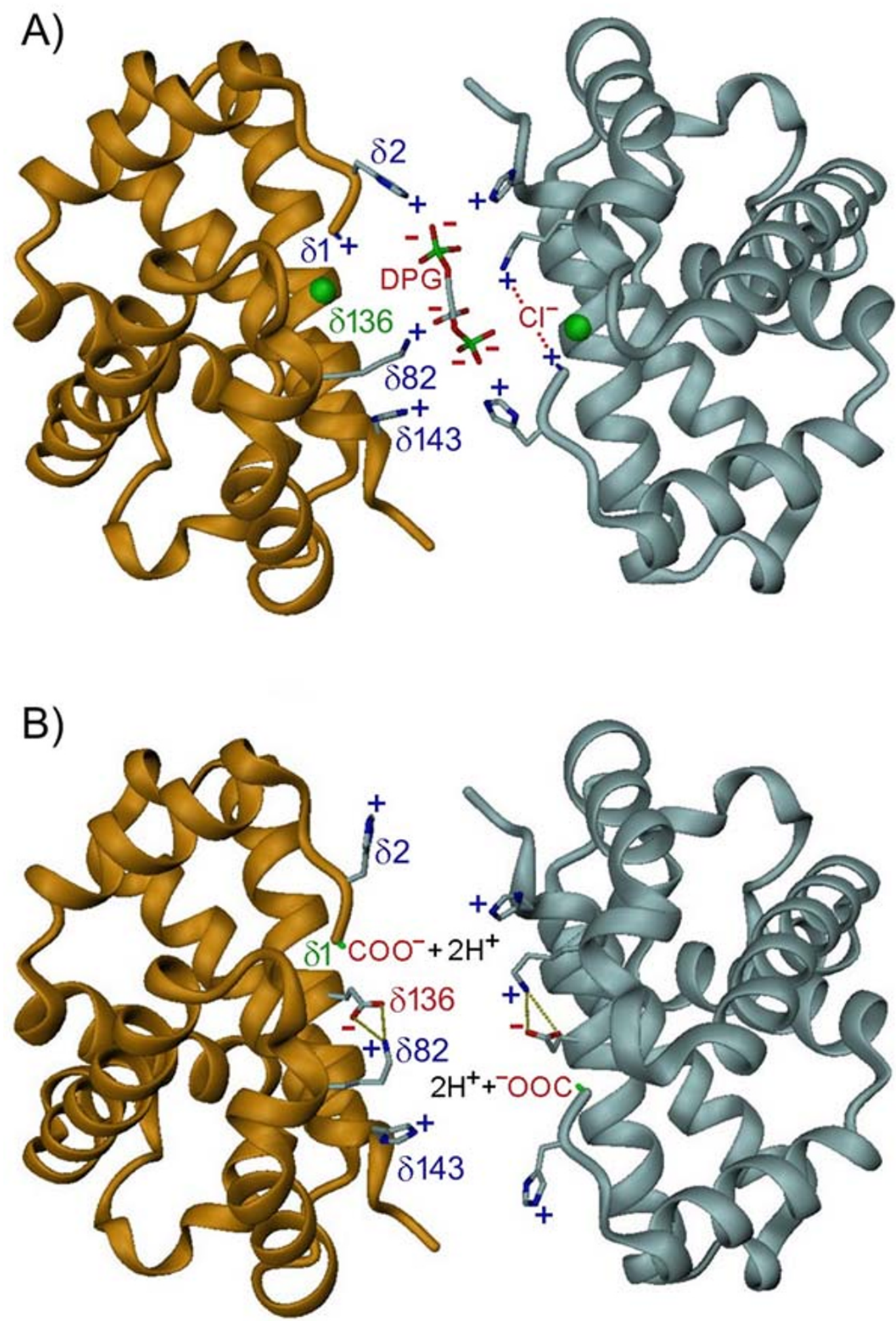

Figure 6 Molecular models of the central cavity between the two $\delta$-globin chains of (A) coast and (B) eastern mole hemoglobins. In coast mole deoxyhemoglobin, this cavity is lined by 8 cationic residues $(\delta 1 \mathrm{Val}, \delta 2 \mathrm{His}$, $\delta 82 \mathrm{Lys}$ and $\delta 143 \mathrm{His}$ ) that form competitive binding sites for anions ( $\mathrm{Cl}$ - lactate and DPG) that stabilize the low $\mathrm{O}_{2}$ affinity T-state conformation. In eastern mole deoxyhemoglobin, the carboxylate side chain of $\delta 136 \mathrm{Glu}$ forms a salt bridge with $\varepsilon$-amino group of $\delta 82$ Lys of the same chain, thus deleting key docking sites for these anions, and reducing competition for

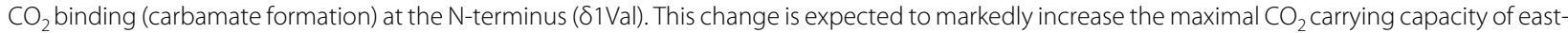
ern mole blood. 
rowing in hypoxic/hypercapnic soils. In fact, a high $\Delta H$ (whereby oxygenation is strongly exothermic) would further exacerbate $\mathrm{O}_{2}$ uptake potential since it increases the heat liberated upon oxygenation in the lungs (which accounts for up to $9 \%$ of metabolic heat production assuming a $\Delta H$ value of $\left.-42 \mathrm{~kJ} \mathrm{~mol}^{-1} \mathrm{O}_{2}[38]\right)$. The precise mechanism underlying the extremely low oxygenation enthalpy phenotype of coast/eastern mole blood is not known, but may be associated with the presence of an 'additional' $\mathrm{Cl}$-binding site in these species (see above).

The negligible effect of DPG on eastern mole Hb (Table $1)$, together with the finding that the erythrocytes of this species are nearly devoid of DPG (Table 3), demonstrates that this organophosphate does not have a central allosteric role in altering its blood $\mathrm{O}_{2}$ affinity. This reduced plasticity may be expected to have potentially adverse consequences since mammals with DPG-insensitive Hbs are unable to modify their $\mathrm{Hb}-\mathrm{O}_{2}$ binding attributes in response to chronic changes in oxygen availability, and hence "are likely to be more restricted physiologically" than those whose oxygen affinity can be altered by increasing/decreasing red cell DPG concentrations [39]. Indeed, it has long been appreciated that cats, cows and sheep - which were subsequently discovered to possess low affinity, DPG-insensitive Hbs [16] - do not adjust well to high altitudes (hypoxia) [40]. Why then have eastern moles, following an extensive period of fossorial evolution (see Figure 1), recently forsaken the potential for adaptive modulation of their $\mathrm{O}_{2}$-binding affinity by phosphates [see e.g. [41]] and adopted a lower whole blood $\mathrm{O}_{2}$ affinity phenotype?

We hypothesize that the loss of DPG binding sharply increases the carrying capacity of eastern mole $\mathrm{Hb}$ for the metabolic end product $\mathrm{CO}_{2}$, thus providing a strong selective advantage for this subterranean inhabitant. Unlike carbon monoxide, $\mathrm{CO}_{2}$ does not bind to the heme iron, but instead can interact with the uncharged $\alpha$ amino termini of the four globin chains to form carbamino $\mathrm{CO}_{2}{ }^{-}[42,43]$. In the absence of DPG (which competes for this same binding site; see below), $70-80 \%$ of all carbamate formation under physiological conditions occurs on the "high affinity" $\beta$-type subunits $[23,27]$. In human $\mathrm{Hb} \mathrm{A}$, the carbamated $\beta$-chain $\mathrm{N}$-termini are able to form intra-chain ionic contacts with $\beta 82$ Lys [43], thus stabilizing the deoxy state molecule (lowering $\mathrm{Hb}^{-} \mathrm{O}_{2}$ affinity). Conversely, the $\delta 136 \mathrm{Gly} \rightarrow$ Glu replacement in eastern mole $\mathrm{Hb}$ (through its neutralization of the cationic charge of $\delta 82 \mathrm{Lys}$ ) should disallow this $\delta 1 \mathrm{Val}-\delta 82 \mathrm{Lys}$ interaction. Indeed, in the absence of DPG, the $\mathrm{CO}_{2}$ effect $\left(\Delta \mathrm{P}_{50}\right)$ $\left.\Delta\left[\mathrm{CO}_{2}\right]\right)$ of the $\mathrm{Hb}$ Hope variant is $70 \%$ lower at a $\mathrm{PCO}_{2}$ of $40 \mathrm{~mm} \mathrm{Hg}$ [23] than in human $\mathrm{Hb} \mathrm{A}$, and nearly $90 \%$ lower at a $\mathrm{PCO}_{2}$ of $80 \mathrm{~mm} \mathrm{Hg}$ [21].
Within the erythrocytes of systemic capillaries, $\mathrm{CO}_{2}$ is largely hydrated to $\mathrm{HCO}_{3}{ }^{-}$and $\mathrm{H}^{+}$by carbonic anhydrase. $\mathrm{HCO}_{3}{ }^{-}$is subsequently exchanged with $\mathrm{Cl}^{-}$via the band 3 protein anion-exchanger, and transported in the plasma [44]. However, band 3 protein anion-exchange appears to be the rate-limiting step in the uptake and offloading of $\mathrm{CO}_{2}$, potentially leading to exchange disequilibra in arteries and veins during severe exercise [44]. In this respect, the $\delta 136$ Gly $\rightarrow$ Glu replacement in the eastern mole $\mathrm{Hb}$ may be significant as it deletes binding sites for anions (i.e., $\mathrm{Cl}^{-}$, lactate and DPG) between $\delta 1 \mathrm{Val}$ and $\delta 82 \mathrm{Lys}$, thus largely freeing the 'high $\mathrm{CO}_{2}$ affinity' $\delta$-chain $\mathrm{N}$-termini from competitive binding constraints. Accordingly, this should result in enhanced binding of $\mathrm{CO}_{2}$ to eastern mole $\mathrm{Hb}$ (two molecules per tetramer) while reducing reliance on the anion-exchanger channel, thus increasing the maximal $\mathrm{CO}_{2}$ carrying capacity of eastern mole blood. In this regard, it should be noted that deoxygenation-linked carbamate formation also liberates a proton from the $\mathrm{N}$-terminal $\alpha$-amino group, which might be expected to increase the Bohr effect of eastern mole $\mathrm{Hb}$ (favouring $\mathrm{O}_{2}$ offloading). However, the $\mathrm{Hb}$ of this species possesses an additional external histidyl residue $(\delta 69 \mathrm{His}$; Figure 4) relative to other moles that should mitigate this effect. Finally, by stabilizing the tense (deoxy) conformation of eastern mole $\mathrm{Hb}$, the $\delta 136 \mathrm{Gly} \rightarrow$ Glu replacement also confers a marked reduction in their whole-blood $\mathrm{O}_{2}$ affinity (a 5-6 mm $\mathrm{Hg}$ increase in their $\mathrm{P}_{50}$ ) compared to coast (see Figure 3) and European moles [1,3,4]. This reduced blood affinity would facilitate the offloading of $\mathrm{O}_{2}$ at a relatively high $\mathrm{PO}_{2}$, leading to a large $\mathrm{O}_{2}$ gradient between the plasma and tissues during burst tunnelling activities. This shift may negatively impact the $\mathrm{O}_{2}$ saturation of eastern mole blood during periods of hypoxia, but is presumably mitigated by elevated blood hematocrit (56.4\%) and $\mathrm{Hb}$ concentrations (19.2 $\mathrm{g} \mathrm{dL}^{-1}$; Table 3 ) compared to coast (46.8\% and $17.4 \mathrm{~g} \mathrm{dL}^{-1}$; [45]), star-nosed (50.5\% and $17.2 \mathrm{~g} \mathrm{dL}^{-1} ;$ [45]), Townsend's (46.4\% and 16.9 $\mathrm{g} \mathrm{dL}^{-1}$; [46]) and European moles $\left(48.7 \%\right.$ and $17.4 \mathrm{~g} \mathrm{dL}^{-1}$; [1]). Eastern moles thus present a novel category of Hbs that appear to be specifically engineered for burst activities in gas-exchange impeded burrows.

\section{Conclusions}

The capacity of certain mammals to withstand low-oxygen environments is thought to largely reside in the enhanced binding affinity of their blood $\mathrm{Hb}$ for oxygen. Here we document that following an extensive period of subterranean evolution, the lineage leading to present day eastern moles adopted a low oxygen affinity, DPG-insensitive blood phenotype - providing the first demonstration of this phenomenon in any mammal chronically 
exposed to hypoxia (and only the fourth known origin of this phenotype among mammals). The primary molecular mechanism involves an amino acid substitution ( $\delta 136 \mathrm{Gly} \rightarrow \mathrm{Glu})$ that forms a salt bridge with $\delta 82 \mathrm{Lys}$ of the same chain, thus deleting key binding sites for allosteric effectors (DPG, $\mathrm{Cl}^{-}$and lactate) between $\delta 1 \mathrm{Val}-$ 882Lys and markedly reducing competition for $\mathrm{CO}_{2}$ binding (carbamate formation) at the $\mathrm{N}$-terminus. Accordingly, we suggest this unique $\mathrm{Hb}$ phenotype enhances $\mathrm{CO}_{2}$ carrying capacity during burst activity (tunnelling) in gas-exchange impeded burrows.

\section{Methods \\ Blood/tissue collection and preparation Hemoglobin}

All study animals were captured and cared for in accordance with the principles and guidelines of the Canadian Council on Animal Care under the authorization of a University-approved animal research protocol (University of Manitoba Animal Use Protocol\# F01-026). Blood samples $(\sim 2 \mathrm{ml})$ were collected from anaesthetized eastern (Nashville, Tennessee) and coast moles (Abbotsford, $\mathrm{BC}$, Canada) and immediately stored at $-80^{\circ} \mathrm{C}$. Samples were subsequently thawed and diluted with 1 volume distilled water, 0.1 vol. 1 M HEPES buffer ( $\mathrm{pH} \sim 7.5)$, and centrifuged for $15 \mathrm{~min}$ at $14,000 \mathrm{RPM}$. Individual isoHb components were isolated by preparative isoelectric focusing in a $110-\mathrm{ml}$ LKB column containing a $1 \%$ solution of CO-saturated ampholines ( $\mathrm{pH}$ range 6.7-7.7; LKB, Sweden) and eluted 1-ml fractions were analyzed for absorption $(540 \mathrm{~nm})$ and $\mathrm{pH}$. Pooled fractions of individual $\mathrm{Hb}$ components were dialysed for 24-36 h against three changes of CO-equilibrated dialysis buffer $(0.01 \mathrm{M}$ HEPES), concentrated by ultrafiltration and frozen at $80^{\circ} \mathrm{C}$ in small aliquots that were thawed individually on ice prior to analyses. Air equilibrated samples showed slight if any spectrophotometric evidence for oxidation $(<$ $5 \%)$.

\section{Whole blood}

Blood samples $(\sim 2 \mathrm{ml})$ were obtained in heparinized syringes via cardiac puncture from a single anaesthetized star-nosed mole (Caddy Lake, MB, Canada) and from coast and eastern moles collected from the same areas, but in different years, as those described above. A small sub-sample $(60 \mu \mathrm{l})$ of blood was immediately transferred to a pre-heated tube $\left(36-37^{\circ} \mathrm{C}\right)$ and $\mathrm{pH}$ determined using a IQ Scientific benchtop ISFET pH meter with PH16-SS stainless steel micro $\mathrm{pH}$ probe.

Forelimb, hindlimb and heart muscles from six additional eastern moles euthanized with an overdose of Isoflurane inhalant anaesthetic were immediately dissected, freeze-clamped in liquid $\mathrm{N}_{2}$, and stored at $-70^{\circ} \mathrm{C}$. Tissue $\mathrm{Mb}$ and buffering capacity were later determined follow- ing the methods of Reynafarje [47] and Castellini and Somero [48] as outlined in McIntyre et al. [45]. Plasma and intraerythrocytic $\mathrm{pH}$ of blood sub-samples were measured using a freeze-thaw technique similar to that outlined by Zeidler and Kim [49]. Blood hematocrit and $\mathrm{Hb}$ concentrations were determined in duplicate following the procedures outlined by McIntyre et al. [45]. Standards were prepared from lyophilized human $\mathrm{Hb}$ (Sigma Hemoglobin Standard number 525-18). Samples were diluted to obtain values within the standard curve, and the $\mathrm{Hb}$ concentrations calculated by multiplying the measured value by the percent dilution. Red cell DPG concentrations were determined spectrophotometrically from four eastern moles with Roche kit Catalog Number 148 334, while those of three additional coast moles were assayed with Sigma Chemical kit No. 665-PA. Eastern mole red cell counts were determined from 1:200 dilutions of blood in Hayem's solution using a Neubauer hemocytometer, and mean corpuscle volume, mean corpuscular $\mathrm{Hb}$ and mean corpuscular $\mathrm{Hb}$ concentration calculated [50]. Similar hematology parameters from a single coast mole were measured in a Sysmex ${ }^{\mathrm{Tm}}$ Model $\mathrm{NE}-8000^{\text {max }}$ hematology analyzer. Mean values between species were compared using a Welch's t-test, which accounts for possible unequal variances between the two sample means.

\section{Oxygen binding measurements Hemoglobin}

Immediately before $\mathrm{O}_{2}$ equilibration determinations, appropriate volumes of water, $0.1 \mathrm{M}$ HEPES buffer, and when applicable, standard $\mathrm{KCl}$ and 2,3-DPG solutions were added to aliquots of purified $\mathrm{Hb}$ components (final $\mathrm{Hb}_{4}$ concentration $0.05 \mathrm{mM}$ ). Oxygen equilibration data were measured in duplicate at 25 and $37^{\circ} \mathrm{C}$ via absorbance changes at $436 \mathrm{~nm}$ using a modified diffusion chamber technique [51]. Ultrathin layers of Hb solutions (3 $\mathrm{\mu l}$ ) were equilibrated alternatively with pure (> 99.998\%) $\mathrm{N}_{2}$ and $\mathrm{O}_{2}$ then subjected to stepwise mixes of $\mathrm{N}_{2}$ and air prepared with two Wösthoff pumps connected in series to ensure full equilibration at each step [51]. $\mathrm{P}_{50}$ and $n_{50}$ values interpolated from Hill plots were calculated from at least 4 equilibration steps between 30 and $70 \%$ saturation for each trial. Following binding measurements, $\mathrm{Cl}^{-}$concentration for each sample was assessed using a CMT19 chloride titrator (Radiometer, Copenhagen, Denmark), and $\mathrm{pH}$ measured in oxygenated subsamples equilibrated to experimental temperatures $(25$ and $37^{\circ} \mathrm{C}$ ) using a Radiometer BMS2 Mk2 Blood Micro system and PHM 64 Research pH meter. Stock solutions of DPG added to Hb samples were assayed using Sigma enzymatic test chemicals. The overall enthalpy of oxygenation $\left(\Delta H, \mathrm{~kJ} \mathrm{~mol}^{-1} \mathrm{O}_{2}\right)$, corrected for the solubilization 
heat of $\mathrm{O}_{2}\left(-12.5 \mathrm{~kJ} \mathrm{~mol}^{-1}\right)$, was calculated from the integrated van't Hoff equation [9].

\section{Whole blood}

Blood-oxygen binding properties were measured by equilibrating small (3-4 $\mu \mathrm{l})$ aliquots of whole blood to $\mathrm{O}_{2}$ tensions ranging from 0 to $190 \mathrm{~mm} \mathrm{Hg}$ using a modified [52] Hem-O-Scan (American Instrument Co, Silver Springs, MD). Initially, measurements were conducted at the typical body temperature $\left(\mathrm{T}_{\mathrm{b}}\right)$ of each species (Eastern mole $=36.0^{\circ} \mathrm{C}$; coast mole $=36.0^{\circ} \mathrm{C}$, KLC, unpublished data; star-nosed mole $=37.7^{\circ} \mathrm{C}$, [53]) at a $\mathrm{PCO}_{2}$ of $38 \mathrm{mmHg}$. This procedure was repeated in $\mathrm{CO}_{2}$-free gas, and the $\mathrm{pH}$ of separate deoxygenated blood sub-samples equilibrated (at $\mathrm{T}_{\mathrm{b}}$ ) to these $\mathrm{PCO}_{2}$ 's were used to calculate $\mathrm{CO}_{2}$ Bohr coefficients. To assess the effect of temperature on oxygen equilibration curves, trials were also conducted at 32 and $40^{\circ} \mathrm{C}$ for each species. Because starnosed moles are semi-aquatic and may exhibit strong regional heterothermy while foraging in cold water, additional trials on blood samples equilibrated to 3, 15 and $36^{\circ} \mathrm{C}$ were conducted. Oxygen equilibration curves were constructed following Severinghaus [54].

\section{DNA/RNA extraction and cDNA library construction}

Genomic DNA was prepared from 100-200 mg of spleen or liver tissue using standard phenol/chloroform extraction procedures. Primers were designed using areas of high sequence identity in the coding, and $5^{\prime}$ and 3 ' flanking regions of orthologous eutherian $\alpha$ - and $\beta$-like globin genes and from the published amino acid sequences for these polypeptide chains of the European mole [5]. To determine appropriate annealing temperatures for each primer pair (see Additional file 1: Table S1), PCR reactions were initially run on $100 \mathrm{ng}$ of template DNA and Taq polymerase using the gradient function of a MJ Research Dyad ${ }^{\mathrm{m}}$ thermal cycler. Following a 5 min denaturation period at $94^{\circ} \mathrm{C}$, a standard three-step PCR protocol was used $\left(94^{\circ} \mathrm{C}\right.$ for $30 \mathrm{sec} ; 48-56^{\circ} \mathrm{C}$ for $15 \mathrm{sec} ; 72^{\circ} \mathrm{C}$ for $60 \mathrm{sec} ; 30$ cycles). The $5^{\prime}$ and $3^{\prime}$ flanking regions of each gene were subsequently obtained using the APAgene ${ }^{\mathrm{Tm}}$ Genome Walking Kit (Bio S\&T Inc., Montreal, PQ). In all cases, amplified PCR products of the desired size range were excised from the $1 \%$ agarose gel and purified using the Qiagen MinElute Gel Extraction Kit. These products were then cloned into Qiagen pDrive cloning vectors and positive clone plasmids purified with the Qiagen QIAprep Spin Miniprep Kit.

Total RNA was extracted from $\sim 80 \mathrm{mg}$ of eastern $(n=$ $3)$ and coast mole $(n=3)$ spleen samples that had been stored in RNAlater (Ambion) using TRIzol ${ }^{\circ}$ reagent, as per the manufactures directions (Invitrogen). The quantity and quality of the recovered RNA was determined using an Ultrospec 3100 pro UV/Visible Spectropho- tometer (Amersham Biosciences). $10 \mu \mathrm{g}$ of total RNA was used to construct a cDNA library using an ExactStart ${ }^{\mathrm{m}}$ Full-Length cDNA Library Cloning Kit (Epicentre Biotechnologies). RNA decapping, 5 ' oligo ligation and first strand cDNA synthesis reactions were performed according to Epicentre Biotechnologies' protocol. Second strand cDNA was synthesized and amplified by a PCR reaction containing a $2 \mu \mathrm{l}$ aliquot of first strand cDNA and $48 \mu \mathrm{l}$ of reaction mix $(0.25 \mu$ of each dNTP $(2.5 \mathrm{mM}), 5 \mu \mathrm{l}$ of $10 \times$ Reaction Buffer (Invitrogen), $1.5 \mu \mathrm{l}$ of $50 \mathrm{mM} \mathrm{MgCl} 2,1 \mu \mathrm{l}$ of each primer (provided with the ExactStart ${ }^{\mathrm{tm}} \mathrm{Kit}$ ), $0.4 \mu \mathrm{l}$ (2.5 Units) of Taq DNA polymerase (Invitrogen) and 38.1 $\mu \mathrm{l}$ of $\mathrm{dd}_{2} \mathrm{O}$ ), using an Eppendorf Mastercycler Gradient thermocycler. Following an initial denaturation period of $95^{\circ} \mathrm{C}$ for 30 seconds, total cDNA was amplified using a 3step PCR protocol $\left(95^{\circ} \mathrm{C}\right.$ for 30 seconds; $60^{\circ} \mathrm{C}$ for $30 \mathrm{sec}-$ onds; $72^{\circ} \mathrm{C}$ for 4 minutes; 20 cycles). The double stranded cDNA was purified by phenol:chloroform extraction then digested with Asc I and Not I restriction enzymes and ligated into $\mathrm{pCDC} 1-\mathrm{K}$ cloning ready vectors according Epicentre Biotechnologies' protocol. $1 \mu \mathrm{l}$ of the ligation reaction was used to transform $50 \mu \mathrm{l}$ of TransforMax $\mathrm{EC} 100^{\text {ma }}$ Chemically Competent E. coli (Epicentre Biotechnologies). The transformation reaction was incubated at $37^{\circ} \mathrm{C}$ with shaking $(225 \mathrm{rpm})$ for $1 \mathrm{~h}$ to allow the expression of the kanamycin resistance gene. In order to establish a cDNA library culture, the entire transformation reaction was used to inoculate Luria Bertani broth (10 ml final volume) containing kanamycin $\left(50 \mu \mathrm{g} \mathrm{ml}^{-1}\right.$ final concentration) and incubated at $37^{\circ} \mathrm{C}$ with shaking $(225 \mathrm{rpm})$ for $18 \mathrm{~h}$. A $3 \mathrm{ml}$ aliquot of this culture was purified using a QIAprep Spin Miniprep Kit to obtain a pure plasmid cDNA library.

\section{Clone selection}

Positive clones were selectively retrieved from the plasmid library using a modified version of the magnetic bead cDNA capture method described by Shepard and Rae [55]. In brief, the plasmid cDNA library was hybridized with biotinylated oligonucleotide probes (which target highly conserved regions of the $\alpha$ - and $\beta$-like globin genes) and blocking oligonucleotides (which correspond to the 5 ' and 3 ' ends of each probe to prevent renaturation of the plasmid DNA; Additional file 2: Table S2). Plasmids that hybridized with a biotinylated probe were bound to streptavidin coated magnetic beads (Dynabeads ${ }^{\circ} \mathrm{M}-280$ Streptavidin, Invitrogen) and then subjected to a series of high stringency washes to remove any plasmids that nonspecifically hybridized with a probe. The remaining plasmids were released from the magnetic beads and transformed into TransforMax ${ }^{\mathrm{mm}} \mathrm{EC} 100^{\mathrm{ma}}$ Chemically Competent E. coli (Epicentre Biotechnologies). Transformed cells were spread on plates containing $50 \mathrm{ml}$ of LB agar, $50 \mu \mathrm{l}$ of Kanamycin $\left(50 \mu \mathrm{g} \mu^{-1}\right), 80 \mu \mathrm{l}$ of X-gal $(40 \mathrm{mg}$ 
$\left.\mathrm{ml}^{-1}\right)$ and $20 \mu \mathrm{l}$ of IPTG $(0.1 \mathrm{M})$ and incubated at $37^{\circ} \mathrm{C}$ for $18 \mathrm{~h}$.

Selected clones were screened for the presence of their respective insert by scraping an isolated colony into a 0.2 $\mathrm{ml}$ PCR tube and adding $15 \mu \mathrm{l}$ of a PCR reaction mix $(0.35 \mu \mathrm{l}$ of each dNTP $(2.5 \mathrm{mM}), 1.5 \mu \mathrm{l}$ of $10 \times$ Reaction Buffer (Invitrogen), $0.6 \mu \mathrm{l}$ of $50 \mathrm{mM} \mathrm{MgCl}{ }_{2}, 0.6 \mu \mathrm{l}$ of each primer (designed from highly conserved regions among mammalian $\alpha$ - and $\beta$-globin genes using Primer Premier 5.0 software), $0.12 \mu \mathrm{l}$ (0.6 Units) of Taq DNA polymerase (Invitrogen) and $10.18 \mu \mathrm{l}$ of $\mathrm{ddH}_{2} \mathrm{O}$ ). Positive clones were used to inoculate $8 \mathrm{ml}$ of LB culture medium containing kanamycin $\left(50 \mu \mathrm{g} \mathrm{ml}^{-1}\right.$ final concentration) and incubated for $18 \mathrm{~h}$ at $37^{\circ} \mathrm{C}$ while shaking at $225 \mathrm{rpm}$. A $3 \mathrm{ml}$ sample of each culture was purified using a QIAprep ${ }^{\circ}$ Spin Miniprep Kit (Qiagen). $2 \mu \mathrm{l}$ of purified plasmid DNA was digested with Eco RI and Hind III (1 $\mu$ l of each enzyme, 2 $\mu \mathrm{l}$ of $10 \times$ React 2 buffer and $14 \mu \mathrm{l}$ of $\mathrm{dd}_{2} \mathrm{O}$ ) and electrophoresed for $1 \mathrm{hr}$ at $100 \mathrm{~V}$ on a $1 \%$ agarose gel (UltraPure $^{\mathrm{Tm}}$, Invitrogen) to confirm the size of the insert.

\section{DNA sequencing}

Sequencing reactions were preformed on $200 \mathrm{ng}$ of purified plasmid DNA using the BigDye ${ }^{\circ}$ Terminator v3.1 Cycle Sequencing Kit (Applied Biosystems) and the universal sequencing primer M-13(R). Reaction mixtures were sequenced using a 4-capillary Applied Biosystems 3130 Genetic Analyzer. Consensus alignments for each gene were constructed using Sequencher ${ }^{\mathrm{m}}$ (Version 4.6) software, and the amino acid compliment of each globin chain was deduced. Sequence data were deposited in GenBank with the accession numbers (AY842447AY842448, HM060229-HM060234 and HM060237HM060243).

\section{Determination of $\mathrm{Hb}$ isoform composition}

After using isoelectric focusing native gels to assess $\mathrm{Hb}$ isoform diversity, the individual globin chain subunits were dissociated and separated by means of Acetic acidUrea-Triton X-100 (AUT) gel electrophoresis [56]. Electrophoretic bands representing dissociated $\alpha$ - and $\beta$-type chain monomers were excised from each AUT gel, digested with trypsin, and identified by means of tandem mass spectrometry (MS/MS; $[57,58])$. The peak lists of the MS/MS data were generated by Distiller (Matrix Science, London, UK) using the charge state recognition and de-isotoping with default parameters for quadrupole time-of-flight data. Database searches of the resultant MS/MS spectra were performed using Mascot (Matrix Science, v1.9.0, London, UK). Specifically, the peptide mass fingerprints were used to query a reference database of $\alpha$ - and $\beta$-like globin sequences that included each of the globin cDNA sequences from the same sample of moles. The following search parameters were used: no restriction on protein molecular weight or isoelectric point, enzymatic specificity set to trypsin, and methionine oxidation allowed as a variable peptide modification. Mass accuracy settings were 0.15 daltons for peptide mass and 0.12 daltons for fragment ion masses. We identified all significant protein hits that matched more than one peptide with $P<0.05$.

\section{Phylogenetic reconstructions}

To infer orthologous relationships of $\beta$-like globin sequences from eastern mole and coast mole, we conducted a phylogenetic survey of nucleotide variation in the $\beta$-like globin genes of six other eutherian mammals. In addition to eastern mole and coast mole, this set of species included three other eulipotyphlan species (Atelerix albiventris [GenBank: AC104389]; Erinaceus europaeus [scaffolds 283493, 67442, and 340990]; and Sorex araneus [AC166888]), as well as human (Homo sapiens [AC104389]), rabbit (Oryctolgus cuniculus [AC166202]), and armadillo (Dasypus novemcinctus [AC151518]). $\beta$-like globin sequences from human, rabbit, and armadillo were included in the phylogenetic analysis because they each possess a closely linked pair of well-characterized $H B B$ and $H B D$ genes [13]. Sequences were aligned using MUSCLE [59], as implemented in the European Bioinformatics Institute web server http:// www.ebi.ac.uk. Since the coding regions of duplicated globin genes are often affected by gene conversion, reliable inferences about orthologous relationships can be obtained by examining intron 2 sequence $[13,14]$. We therefore performed phylogenetic reconstructions based on both coding sequence (477 bp) and intron 2 sequence (938 bp). We inferred phylogenetic relationships among the $\beta$-like globin sequences in a maximum likelihood framework using Treefinder, version April 2008 [60], and we assessed support for each node with 1000 bootstrap pseudoreplicates. We selected the best-fitting model of nucleotide substitution for each of the two data partitions using the Bayesian Information Criterion in Treefinder. Phylogenetic reconstructions of the coding and intronic sequences were conducted using the $\mathrm{HKY}+\gamma$ and $\mathrm{TN}+\gamma$ models, respectively.

\section{Molecular modeling}

Amino-acid substitutions of both mole species (relative to human $\mathrm{Hb} \mathrm{A}$ ) were inserted into the 3D T-state deoxy structures of human $\mathrm{Hb}$ with DPG absent (eastern mole model from PDB 2DN2) and present (coast mole model from PDB 1B86). Structural homology models of eastern mole and coast mole Hbs were then prepared using the MODELLER function of the Insight II program package version 97.2 (Biosym Technologies, San Diego, CA). The strain energy in the vicinity of the central cavity between the $\delta$-chains of both $\mathrm{Hb}$ models were generated sepa- 
rately in the GROMOS force field using the 53A6 parameter set optimized for molecular dynamics simulations [61]. For each substitution the strain energy was subsequently minimized using the GROMACS package (version 3.3). This involved a brief steepest descents run that employed a maximum step size protocol of $1 \AA$, and a maximum tolerance of $1000 \mathrm{~kJ} \mathrm{~mol}^{-1} \mathrm{~nm}^{-1}$. This was followed by a more extensive conjugate gradients minimization with a tolerance of $100 \mathrm{~kJ} \mathrm{~mol}^{-1} \mathrm{~nm}^{-1}$. A Morse oscillator model was used to represent covalent bonding in the conjugate gradients minimization step, while a harmonic oscillator approximation was utilized for the steepest descents protocol. For the eastern mole modelling, the N-terminus was initially set to a charge of +0.5 . Under these conditions, two equally likely intra-chain electrostatic interactions were present: Glu $\delta 136-$ Lys $\delta 82$

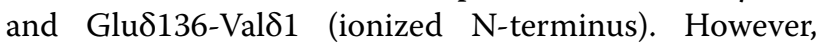
given that the former bond is much more stable than the latter, the equilibrium shifts solely to the Glu $\delta 136-$ Lys $\delta 82$ formation over multiple iterations. This same association is exclusively found when the $\mathrm{N}$-terminus was given a neutral charge. Three-dimensional molecular representations were visualized with DINO version 0.9.1 [62].

\section{Additional material}

Additional file 1 Table S1. Primers used to amplify the $H B A$ and $H B D$ genes from coast and eastern mole DNA.

Additional file $\mathbf{2}$ Table S2. Oligonucleotides used to probe the $H B A$ and HBD genes from coast and eastern mole cDNA.

\section{Authors' contributions}

KLC and REW designed research; KLC, JFS, JS, AVS, AP and JB performed research; KLC, JS, JFS, HM, KC, JB and REW contributed new reagents/analytic tools; KLC, JS, AVS, JFS and HM analyzed data; KLC drafted the manuscript; and KLC, JFS and REW contributed to the final manuscript writing and its revisions. All authors have read and approved the final manuscript

\section{Acknowledgements}

We thank R. Gusztak and S.T. Sheehan for aid in procuring blood samples and A. Bang for technical support. M. Krogh Larsen, A. Sloan and J. Howatt provided valuable assistance with gene sequencing, while N. Lovejoy, G. Valdimarsson and $\mathrm{O}$. Westergaard kindly provided lab space and equipment for components of this work. This research was supported by grants from the Natural Sciences and Engineering Research Council (NSERC) of Canada (KLC, JS), the National Institutes of Health (JFS), the National Science Foundation (JFS), the Nebraska Tobacco Settlement Biomedical Research Development Fund (HM), the Danish Natural Science Research Council (REW), and the Carlsberg Foundation (REW).

\section{Author Details}

1Department of Biological Sciences, University of Manitoba, Winnipeg, MB R3T 2N2 Canada, 2 School of Biological Sciences, University of Nebraska, Lincoln, NE 68588, USA, ${ }^{3}$ Department of Biological Sciences, Vanderbilt University,

Nashville, TN 37235, USA, ${ }^{4}$ Duke University Medical Center and Nicholas School of the Environment Marine Laboratory, Beaufort, NC 28516, USA, 5Department of Chemistry, University of Manitoba, Winnipeg, MB R3T 2N2 Canada and ${ }^{6}$ Zoophysiology, Institute of Biological Sciences, University of Aarhus, Aarhus, DK 8000, Denmark
References

1. Quilliam TA, Clarke A, Salsbury AJ: The ecological significance of certain new haematological findings in the mole and hedgehog. Comp Biochem Physiol A 1971, 40:89-102.

2. Schaefer VH, Sadleir RMFS: Concentrations of carbon dioxide and oxygen in mole tunnels. Acta Theriol 1979, 24:267-276.

3. Bartels $H$, Schmelzle R, Ulrich S: Comparative studies of the respiratory function of mammalian blood. V. Insectivora: shrew, mole and nonhibernating and hibernating hedgehog. Respir Physio/ 1969 7:278-286.

4. Jelkmann W, Oberthür W, Kleinschmidt T, Braunitzer G: Adaptation of hemoglobin function to subterranean life in the mole, Talpa europaea. RespirPhysiol 1981, 46:7-16.

5. Kleinschmidt T, Jelkmann W, Braunitzer G: Die primärstruktur des hämoglobins des maulwurfs (Talpa europaea). Hoppe-Seyler's Z Physiol Chem 1981, 362:1263-1272.

6. Shinohara A, Campbell KL, Suzuki H: Molecular phylogenetic relationships of moles, shrew moles, and desmans from the new and old worlds. Mol Phylogenet Evol 2003, 27:247-258.

7. Motokawa M: Phylogenetic relationships with the Family Talpidae (Mammalia: Insectivora). J Zool 2004, 263:147-157.

8. Whidden HP: Comparative mycology of moles and the phylogeny of the Talpidae (Mammalia, Lipotyphla). Am Museum Novitates 2000, 3294:1-53.

9. De Rosa MC, Castagnola M, Bertonati C, Galtier A, Giardina B: From the Arctic to fetal life: physiological importance and structural basis of an 'additional' chloride-binding site in haemoglobin. Biochem J 2004, 380:889-896.

10. Lahiri S: Blood oxygen affinity and alveolar ventilation in relation in body weight in mammals. Am J Physiol 1975, 229:529-536.

11. Perutz MF, Fogg JH, Fox JA: Mechanism of deamidation in haemoglobin Providence Asn. J Mol Biol 1980, 138:669-670.

12. Paleari R, Paglietti E, Mosca A, Mortarino M, Maccioni L, Satta S, Cao A, Galanello R: Posttranslational deamidation of proteins: the case of hemoglobin J Sardegna [a50(CD8)HisTAsnTAsp]. Clin Chem 1999, 45:21-28.

13. Opazo JC, Hoffmann FG, Storz JF: Differential loss of embryonic globin genes during the radiation of placental mammals. Proc Natl Acad Sci USA 2008, 105:12950-12955.

14. Opazo JC, Sloan AM, Campbell KL, Storz JF: Origin and ascendency of a chimeric fusion gene: the $\beta / \delta$-globin gene of paenungulate mammals. Mol Biol Evol 2009, 26:1469-1478.

15. Douady CJ, Douzery EJP: Hedgehogs, shrews, moles, and solenodons (Eulipothyphla). In The Timetree of Life Edited by: Hedges SB, Kumar S. Oxford University Press; 2009:495-498.

16. Bunn HF: Differences in the interaction of 2,3-diphosphoglycerate with certain mammalian hemoglobins. Science 1971, 172:1049-1050.

17. Perutz MF: Species adaptation in a protein molecule. Mol Biol Evol 1983, $1: 1-28$.

18. Perutz MF, Fermi G, Poyart C, Pagnier J, Kister J: A novel allosteric mechanism in haemoglobin: structure of bovine deoxyhaemoglobin, absence of specific chloride-binding sites and origin of the chloridelinked Bohr effect. J Mol Biol 1993, 232:536-545.

19. Perutz MF, Imai K: Regulation of oxygen affinity of mammalian haemoglobins. J Mol Biol 1980, 138:649-670.

20. Thillet J, Caburi J, Brun B, Cohen-Solal M, Garel MC, N'Go Minh M, Rosa J: Abnormal functional properties of $\mathrm{Hb}$ Hope $\left(a_{2} \beta_{2} 136(\mathrm{H} 14) \mathrm{Gly} \rightarrow \mathrm{Asp}\right)$. FEBS Letts 1974, 47:47-52.

21. Enoki Y, Ogha Y, Furukawa K, Takaya A, Sakata S, Kohzuki H, Shimizu S, Tsujii T: Hb Hope, $\beta 136(H 14) G l y \rightarrow$ Asp, in a diabetic Japanese female and its functional characterization. Hemoglobin 1989, 13:17-32.

22. Perutz MF, Lehmann H: Molecular pathology of human haemoglobin. Nature 1968, 219:902-909.

23. Bauer C, Baumann R, Engels U, Pacyna B: The carbon dioxide affinity of various human hemoglobins. J Biol Chem 1975, 250:2173-2176.

24. Steinberg MH, Lovell WJ, Wells S, Coleman M, Dreiling BJ, Adams JG: Hemoglobin Hope: studies of oxygen equilibrium in heterozygotes, hemoglobin S-Hope disease, and isolated hemoglobin Hope. J Lab Clin Med 1976, 88:125-131.

25. Minnich V, Hill RJ, Khuri PD, Anderson ME: Hemoglobin Hope: a betachain variant. Blood 1965, 25:830-838. 
26. Garner MH, Bogardt RA Jr, Gurd FR: Determination of the pK values for the alpha-amino groups of human hemoglobin. J Biol Chem 1975 , 250:4398-4404

27. Gros G, Rollema HS, Forster RE: The carbamate equilibrium of $a-$ and $\varepsilon$ amino groups of human hemoglobin at $37^{\circ} \mathrm{C}$. J Biol Chem 1981, 256:5471-5480.

28. Moo-Penn WF, Bechtel KC, Schmidt RM, Johnson MH, Jue DL, Schmidt DE, Dunlap WM, Opella SJ, Bonaventura J, Bonaventura C: Hemoglobin Raleigh ( $\beta 1$ valineTacetylalanine). Structural and functional characterization. Biochemistry 1977, 16:4872-4879.

29. Harano T, Harano K, Ueda S, Imai K, Ohkuma A, Koya Y, Takahashi H: Hb Fukuoka [ $\beta 2$ (NA2) HisTTyr]: a new mutation at the 2,3diphosphoglycerate binding site. Hemoglobin 1990, 14:199-205.

30. Bare GH, Alben JO, Bromberg PA, Jones RT, Brimhall B, Padilla F: Hemoglobin Little Rock ( $\beta 143$ (H21) HisTGIn). Effects of an amino acid substitution at the 2,3-diphosphoglycerate binding site. J Biol Chem 1974, 249:773-779.

31. Bonaventura C, Bonaventura J: Anionic control of function in vertebrate hemoglobins. Am Zool 1980, 20:131-138.

32. Sugihara J, Imamura T, Nagafuchi S, Bonaventura J, Bonaventura C, Cashon R: Hemoglobin Rahere, a human hemoglobin variant with amino acid substitution at the 2,3-diphosphoglycerate binding site. Functional consequences of the alteration and effects of bezafibrate on the oxygen bindings. J Clin Invest 1985, 76:1169-1173.

33. Bonaventura J, Bonaventura C, Sullivan B, Ferruzzi G, McCurdy PR, Fox J, Moo-Penn WF: Hemoglobin Providence. Functional consequences of two alterations of the 2,3-diphosphoglycerate binding site at position beta 82. J Biol Chem 1976, 251:7563-7571.

34. Frier JA, Perutz MF: Structure of human foetal deoxyhaemoglobin. J Mol Biol 1977, 112:97-112.

35. Dickerson RE, Geis I: Hemoglobin: Structure, function, evolution, and pathology. Menlo Park: Benjamin/Cummings Publishing Company; 1983.

36. Benesch RE, Benesch $\mathrm{R}$ : The reaction between diphosphoglycerate and hemoglobin. Fed Proc 1970, 29:1101-1104

37. Brix O, Bårdgard A, Matheisen S, Tyler N, Nuutinen M, Condo SG, Giardina $B$ : Oxygen transport in the blood of arctic mammals: adaptation to local heterothermia. J Comp Physiol B 1990, 159:665-660.

38. Weber RE, Wells RMG: Hemoglobin structure and function. In Lung Biology in Health and Disease. Comparative Pulmonary Physiology, Current Concepts Edited by: Wood SC. New York: Marcel Dekker, Inc; 1989:279-310.

39. Bunn HF, Forget BG: Hemoglobin: Molecular, Genetic and Clinical Aspects. Philadelphia: W.B. Saunders Company; 1986.

40. Pearson OP: Mammals in the highlands of southern Peru. Bull Mus Comp Zool 1951, 106:1-174

41. MacArthur RA: Seasonal changes in haematological and respiratory properties of muskrat (Ondatra zibethicus) blood. Can J Zool 1984 62:537-545.

42. Rossi-Bernardi L, Roughton FJW: The specific influence of carbon dioxide and carbamate compounds on the buffer power and Bohr effects of human haemoglobin solutions. J Physiol 1967, 189:1-29.

43. Fantl WJ, Di Donato A, Manning JM, Rogers PH, Arnone A: Specifically carboxymethylated hemoglobin as an analogue of carbamino hemoglobin. Solution and X-ray studies of carboxymethylated hemoglobin and X-ray studies of carbamino hemoglobin. J Biol Chem 1987, 262:12700-12713

44. Jensen FB, Wang T, Jones DR, Brahm J: Carbon dioxide transport in alligator blood and its erythrocyte permeability to anions and water. Am J Physiol 1998, 274:R661-R671.

45. Mclntyre IW, Campbell KL, MacArthur RA: Body oxygen stores, aerobic dive limits and diving behaviour of the star-nosed mole (Condylura cristata) and comparisons with non-aquatic talpids. J Exp Biol 2002, 205:45-54.

46. Pedersen RJ: The life history and ecology of Townsend's mole Scapanus townsendii (Bachman) in Tillamook County Oregon. MSc thesis. Oregon State University, Biology Department; 1963.

47. Reynafarje B: Simplified method for the determination of myoglobin. $J$ Lab Clin Med 1963, 61:138-145.

48. Castellini MA, Somero GN: Buffering capacity of vertebrate muscle: correlations with potentials for anaerobic function. J Comp Physiol B 1981, 143:191-198.

49. Zeidler R, Kim HD: Preferential hemolysis of postnatal calf red cells induced by internal alkanlinization. J Gen Physiol 1977, 70:385-401.
50. Schalm OW, Jain NC, Carroll EJ: Veterinary hematology. 3rd edition Philadelphia: Lea and Febiger; 1975.

51. Weber RE: Use of ionic and zwitterionic (Tris/BisTris and HEPES) buffers in studies on hemoglobin function. J App/ Physio/ 1992, 72:1611-1615.

52. Lapennas GN, Colacino JM, Bonaventura J: Thin-layer methods for determination of oxygen binding curves of hemoglobin solutions and blood. Methods Enzymol 1981, 76:449-470.

53. Campbell KL, McIntyre IW, MacArthur RA: Fasting metabolism and thermoregulatory competence of the star-nosed mole, Condylura cristata (Talpidae: Condylurinae). Comp Biochem Physiol A 1999, 123:293-298.

54. Severinghaus JW: Simple, accurate equations for human blood $\mathrm{O}_{2}$ dissociation computations. J App/ Physiol 1979, 46:599-602.

55. Shepard AR, Rae JL: Magnetic bead capture of CDNAs from doublestranded plasmid cDNA libraries. Nucl Acids Res 1997, 25:3183-3185.

56. Pirastru M, Manca L, Palici di Suni M, Speziga SM, Masala B: Hb F-Porto Torres [ ${ }^{A} \gamma 75(E 19)$ IleTThr, 136(H14)AlaTSer]: a novel variant of the ${ }^{A} Y$ chain having two substitutions, one being that of $\mathrm{Hb}$ F-Sardinia. Hemoglobin 2004, 28:297-303.

57. Rohila JS, Chen M, Chen J, Cerny R, Dardick C, Canlas P, Xu X, Gribskov M, Kanrar S, Zhu J-K, Ronald P, Fromm ME: Protein-protein interactions of tandem affinity purification-tagged protein kinases in rice. Plant $J$ 2006, 46:1-13

58. Nakachi M, Hoshi M, Matsumoto M, Moriyama H: Conserved sequences of sperm-activating peptide and its receptor throughout evolution, despite speciation in the sea star Asterias amurensis and closely related species. Zygote 2008, 16:229-237.

59. Edgar RC: MUSCLE: multiple sequence alignment with high accuracy and high throughput. Nucl Acids Res 2004, 32:1792-1797.

60. Jobb G, von Haeselern A, Strimmer K: TREEFINDER: a powerful graphical analysis environment for molecular phylogenetics. BMC Evol Biol 2004, 4:18.

61. Oostenbrink C, Villa A, Mark AE, van Gunsteren WF: A biomolecular force field based on the free enthalpy of hydration and solvation: The GROMOS force-field parameter sets 53A5 and 53A6. J Comput Chem 2004, 25:1656-1676

62. Philippsen A: DINO: Visualizing Structural Biology. 2002 [http:// www.dino3d.org]. University of Basal

doi: $10.1186 / 1471-2148-10-214$

Cite this article as: Campbell et al., Molecular basis of a novel adaptation to hypoxic-hypercapnia in a strictly fossorial mole BMC Evolutionary Biology 2010, 10:214

\section{Submit your next manuscript to BioMed Centra and take full advantage of:}

- Convenient online submission

- Thorough peer review

- No space constraints or color figure charges

- Immediate publication on acceptance

- Inclusion in PubMed, CAS, Scopus and Google Scholar

- Research which is freely available for redistribution 